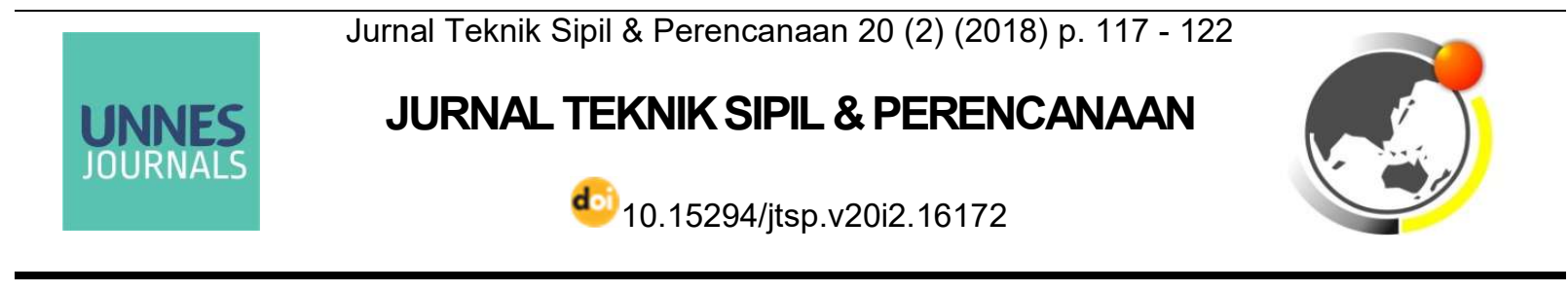

\title{
The Evaluation of Foreman Competency Suitability on Consumer Complaints
}

\author{
Yaffi Arrizki Kusumanugraha ${ }^{1, \text { a) }}$ and Retna Kristiana ${ }^{1}$ \\ ${ }^{1}$ Civil Engineering Department, Mercu Buana University \\ a) Corresponding author: yaffiarrizki@gmail.com
}

\begin{abstract}
The construction industry is one of the most developed industries around the world. Similar to the housing construction industry, consumers who buy a house on the developers sometimes have a complaint about the units they buy. Because of the consumer complaints, the developers expend more money to use the services of foreman complaints. Quality of foreman complains determines the result of consumer complaint work. Elements of competence that affect the performance of the foreman complain were analyzed using SPSS and descriptive percentage. Descriptive method of percentage of frequency calculated in percent. The elements analyzed are the skills competence, the work experience competence, the discipline competence and the wage competency. The results of the research showed that the elements that affected the foreman complaints are the skills competence $88.56 \%$, the work experience competence $85.56 \%$, the skills competence $88.56 \%$ the discipline competence $89.07 \%$ and the wage competency $89.73 \%$. The strategies that must be implemented to improve the performance of the foreman complain are to supervise the continues improvement of the team owner, and also repeat orders according to the portion (the foreman capacity), selecting the workman or labor that will be used by the foreman to do a job and also make a skill assessment from the foreman and his team, conducting training programs for the foreman and the craftsman can also be a strategy to improve the performance of the foreman complain.
\end{abstract}

\section{INTRODUCTION}

The construction industry is one of the most developed industries in the world. The growth of the construction industry is in line with the growth in a country [1]. People always need houses as a place to live and also to stay [2]. Consumers who have bought houses on the housing developer have complaints about the unit.

Because of these consumer complaints, the developer employs the services of construction complaint foreman. This condition occurs if the contractor has submitted the $2^{\text {nd }}$ project handover (BAST2). According to [1], the foreman is a term for people who are assigned to supervise, head, and are responsible for a group of people or workers in the field. One of the important functions that must be in construction is supervision [1]. The construction complaint foreman is a term for people who are given an assignment by PT Jaya Real Property to carry out consumer complaint work or home stock repairs [3].

\section{Housing}

According to Government Regulation No. 14 of 2016 concerning the Implementation of Housing and Settlement Areas, houses are buildings that function as suitable dwellings, facilities for family development, a socioeconomic symbol of the occupants, as well as assets for their owners. The house as one of the basic needs of the man who can function as a means of family production is a strategic point in full human development and is the entry point to the 
world that promises to fulfill other basic needs [4]. The increasing need for housing has encouraged the government and the private sector to establish housing businesses in various types.

In accordance with Government Regulation No. 14 of 2016 concerning the Implementation of Housing and Settlement Areas, housing is a collection of houses as part of Settlements, both urban and rural, which are equipped with Infrastructure, Facilities, and Public utilities as a result of efforts to fulfill proper houses.

\section{Complaints}

Consumer complaints occurs when a product and or service used by consumers is not as desired [5]. Customer complaints can become resources that have not been optimally utilized because complaints contain a lot of information about consumers and products and can be used as a foundation for the formation of the power of products and services [5]. Complaints indicate a feeling of resentment or disappointment on a certain service. Complaints or complaints are expressions of dissatisfaction from customers with the services provided by the company. According [5], complaints consist of 2 types, namely:

- Complaints that are delivered verbally through telephone and direct communication

- Complaints submitted in written forms through the guest complaint form.

\section{Foreman}

The workforce in the construction project is supervised by an experienced workforce with expertise and experience known as the foreman [6]. Poerwadarminta in [7] defines the foreman as the leader or supervisor of the workforce. [7] states that the foreman is an employer and contractor for the procurement of workforce as well as providing solution on a particular job.

\section{Construction Foreman}

According to [6] the workforce in the construction project is headed by an experienced workforce with expertise and experience known as the foreman. In the process of building a house in the Bintaro area, PT Jaya Real Property uses the services of a contractor who was given a work order to finish the project. The contractor in the development process later employed the construction foreman to supervise and head the workers in the project. Therefore, the construction foreman is under contractor who gets a working order from PT Jaya Real Property.

\section{The Complaint Foreman}

A complaint foreman is the name for the foreman who handles the job of a consumer complaint. According to [3], the complaint foreman is the designation for the person assigned by PT. Jaya Real Property to carry out consumer complaints work or home stock repairs. The complaint foreman which was assigned to do work by PT. Jaya Real Property was paid directly by PT. Jaya Real Property. The foreman of complain eventually obtained a work order directly from PT. Jaya Real Property.

\section{Duties and Functions of the Foreman}

The foreman has an important function in construction. [8] revealed that the foreman coordinates a lot of construction workers. According to [7], 95.63\% of the construction workforce are labor and hired workers who are generally under the foreman. While the foreman's leadership is the skills and advantages especially in the field of construction projects, so he is able to manage labor to jointly perform project work in accordance with the specified [7]. Therefore, the function of the foreman is to manage labors working on a project to work smoothly. 


\section{The Competence of the Complaint Foreman}

Performance is a condition that must be known and confirmed to certain parties to know the level of achievement of an agency results related to the vision of an organization or company and to know the positive and negative impact of an operational policy, Soeharto in [7], the performance of the foreman is a result of work achieved by the foreman in carrying out tasks assigned to him based on skills, experience and seriousness and time. In the construction of Bintaro project, the performance of the complaint foreman is assessed by the owner as the assignor. Performance of the foreman is based on:

1. Skills. The skills of the foreman greatly affect his performance, the skills are indicated by how a foreman solved a problem. The foreman should read and understand the drawing sheet and translate them into operational steps. [6]. According to [8], the higher value of skills led to the higher value of building quality.

2. Work experience. Work experience is the level of one's understanding of the work [8]. A skill and experience are required to analyze a particular situation in the field to work according to each skill [1].

3. Skills. Monitoring of labor and materials and equipment was performed before the start of the construction period where this stage is the initial stage so that the whole series of construction process can run well [6]. If the foreman is less capable then the work will run less smoothly. According to [9] the foreman is very important to provide guidance to employees while doing the work so that employees are willing to work hard to achieve optimal results.

4. Discipline. Supervision of labor is very important to achieve job satisfaction and the expected results [6]. According to [7], the foreman performs the entire implementation of the work in accordance with the instructions given by the manager and or the ranks above.

5. Wages. Labor costs are negotiated to obtain how payrolls are made and calculate the amount of daily wages for workers [6]. Wages received on time [10].

\section{METHODOLOGY}

The research location was in the Bintaro Jaya housing development project. This location was chosen because there were still a number of consumer complaints works done by the foreman. The data taken were the primary data, namely questionnaires from PT Jaya Real Property supervisors and secondary data, namely consumer complaints. After the data obtained both secondary data and primary data then the data were processed again using SPSS program to support in data analysis.

\section{Validation Test}

In this validity test can later show how far the level of accuracy of the use of measuring instruments against the symptoms to be measured. The questionnaire can be said to be valid if the question in a questionnaire or questionnaire is able to reveal something that will be measured by the questionnaire [7]. According to [7], the validity of an instrument can be determined by comparing the correlation index of Product Moment Person with a significant level of $0.05(5 \%)$ as its critical value by comparing $r_{\text {stats }}$ with $r_{\text {table }}$ then it can be determined the validity of the instrument with the following criteria :

$\mathrm{r}_{\text {stats }}>\mathrm{r}_{\text {table }}$ : Valid

$r_{\text {stats }}<r_{\text {table: }}$ Invalid

\section{Reliability Test}

Reliability is an index that indicates the extent to which a gauge can be trusted or reliable. In other words, reliability shows the consistency of a measuring device in measuring the same symptoms [7]. If the alpha is between $0.7-0.9$ then it is stated high reliability. Descriptive percentage was processed by means of relative frequency. The relative frequency is the frequency calculated in percent form as expressed by [1]. The formula used for descriptive percentage calculation is as follows Subana and Sudrajat in [11]: 
Information:

Percentage $=\frac{(\Sigma \text { (Answer } \times \text { Weight of Each Choice }))}{(\mathrm{n} \times \text { Top Weight })} \times 100 \%$

$\Sigma=$ the sum of all answers

$\mathrm{n}=$ Total number of questionnaire items

according to [11], to calculate the percentage of all subjects used by using the following formula:

Information:

$$
\text { Percentage }=\frac{F}{N}
$$

$\mathrm{F}=$ Total percentage of the entire subject

$\mathrm{N}=$ number of subjects

\section{RESULT AND DISCUSSION}

\section{Validity Test}

The results of the validity test showed that $r$ statistic is greater than its critical value. In the above validity test results, there were 2 indicators of 30 indicators that the value of the variable is still below 0.3061 and the value of significance above 0.1 , then the item was considered invalid from 30 indicators. Then the second stage validity test was performed, by excluding the invalid items, X020 with the r value 0.266 and X029 with the $\mathrm{r}$ value of 0.224 . As well as to set the number of work, the X020 and X029 were also excluded, because the correlation values that exist in the performance of X020 and X029 below r table value. According to [12], there are several ways that can be done on invalid questionnaire items:

1. Fix the invalid items in the questionnaire then share them to the respondent to be answered again. The question must be better than before and the researcher must make sure that the respondent asks the question seriously This method requires a lot of time so the author does not use this way

2. To eliminate invalid questionnaire. This is performed if a valid variable still represents the problem in the research. The author employed this method because of the limited time of conducting this study.

Therefore, those two invalid items were eliminated. The results of the second item test showed that 28 items were valid.

\section{Reliability Test}

Based on the reliability test results note that the value of Cronbach's Alpha figures for foreman complaints of 0.883. So it can be concluded that the research instrument used to measure the variables on the questionnaire can be considered reliable.

\section{Descriptive percentage}

The percentage descriptive analysis is aimed at obtaining the main competency element affecting the competence of the foreman complain at Bintaro Jaya Housing Project, South Tangerang. In this study the performance scale can be seen in table 1 below.

TABLE 1. Percentage of performance for the complaint foreman

\begin{tabular}{cccl}
\hline No & Persentage & Result & \\
\hline $\mathbf{1}$ & $>81$ & $\begin{array}{l}\text { Very } \\
\text { Good }\end{array}$ & $\begin{array}{l}\text { The complaint foreman is very good at leading, managing and supervising } \\
\text { a project }\end{array}$ \\
$\mathbf{2}$ & $71 \%-80 \%$ & Good & $\begin{array}{l}\text { The complaint foreman complaint is good both in leading, managing and } \\
\text { supervising a project } \\
\text { The complaint foreman is good enough in leading, managing and } \\
\text { supervising a project }\end{array}$ \\
\hline
\end{tabular}




\begin{tabular}{llll}
\hline $4<60 \%$ & Less & $\begin{array}{l}\text { The complaint foreman is not good at leading, managing and supervising a } \\
\text { project }\end{array}$ \\
\hline
\end{tabular}

Source: [6]

After calculating each performance, then the average of each competency element was performed. The calculation results are below.

TABLE 2. Percentage of competitor foreman compliance performance element

\begin{tabular}{clccc}
\hline No. & Element of Competency & Value Maximum & Percentage of & Results \\
\hline $\mathbf{1 .}$ & Skill & $100 \%$ & $88.56 \%$ & Very good \\
$\mathbf{2}$. & Work Experience & $100 \%$ & $85.56 \%$ & Very good \\
$\mathbf{3}$ & Skills & $100 \%$ & $88.56 \%$ & Very good \\
$\mathbf{4}$ & Discipline & $100 \%$ & $89.07 \%$ & Very good \\
$\mathbf{5}$ & Wages & $100 \%$ & $89.73 \%$ & Very good \\
\hline & $\begin{array}{c}\text { Average percentage of } \\
\text { competence element foreman } \\
\quad \text { complain }\end{array}$ & & $88.29 \%$ & Very good \\
\hline
\end{tabular}

The evaluation of the competence of the complaint foremen on the Bintaro Jaya Housing Development Project, South Tangerang showed that the average of the five elements of competency of the complaint foreman in the Bintaro Jaya Housing Development Project is $88.29 \%$. From the five elements of competence above, the results of the performance of the complaint foreman are very good.

The expert validation was conducted to ask for suggestions to take corrective action on the results. The competency elements of the complaint foreman performance are very good. However, it still needs improvement to minimally maintain existing ones, even improve the complaint foreman performance, the selection of appropriate strategies can improve the performance of the foreman complaint in the future. The expert validation for complaints supervisor performance election strategy suggested these following actions:

- Conducting continuous improvement supervision from the owner

- Repeating orders based on the portion (foreman capacity)

- Selecting a worker or workforce to be used by the foreman to do a job

- Making a skill assessment of the foreman and his team

- Establishing training programs for foremen and workers.

\section{CONCLUSIONS}

The competence elements of the complaint foreman who influenced the performance of the complaint foreman are as follows: skill competence indicators with 6 performances, work experience competence indicators with 6 performances, competency indicators with 6 performances, discipline competence indicators with 6 performances, and indicators of wage competence of 6 performances.

The main competency element affecting the performance of the complaint foreman is a wage competency element with the percentage of $89.73 \%$ with the performance of wage paying to the complaint foreman shall be in accordance with the agreement which has been mutually agreed between the owner and the recipient of the work.

The strategies which are considered to improve the performance of the foreman of complaints on the Bintaro Jaya housing project, South Tangerang are as follows:

- Continuous improvement from the team owner

- $\quad$ Repeating orders (foreman capacity)

- Selecting the workforce or labor

- Assessing the skills of the foreman and team based on job referrals

- Providing training programs to maintain or improve existing skills 


\section{ACKNOWLEDGEMENT}

Thanks to my mentor Ms. Retna Kristiana ST, MT who has provided input and guidance during the writing of this journal.

\section{REFERENCES}

[1] N. Y. Utami and Syahrizal, Penilaian Kualifikasi Pengetahuan dan Keterampilan Mandor Pada Bangunan Gedung di Medan Berdasarkan SKKNI. 2017.

[2] M. Roestamy and A. Suharmiko, "Perlindungan Hukum Terhadap Konsumen Perumahan Real Estate Berbasis Brosur," Living Law, vol. 8, pp. 103-114.

[3] P. J. R. Property, Standar Operasional Perusahan. 2008.

[4] L. Mulyadi, A. A. Santoso, and M. Sulton, "Faktor-Faktor yang Berpengaruh terhadap Mutu Produk Bangunan Perumahan Grand Permata di Kabupaten Mojokerto," Info Manaj. Proy., vol. 4, pp. 38-48.

[5] V. R. Berthama, "Faktor - Faktor Penyebab Komplain Konsumen Pada PT Pegadaian (Persero) Cabang Karombasan Manado," Ris. Bisnis dan Manaj., vol. 2, pp. 44-59, 2014.

[6] C. M. Ayanggela, Rafie, and R. Pratiwi, "Pengaruh Kompetensi Mandor terhadap Waktu Pelaksanaan Proyek Konstruksi (Studi Kasus : Proyek Qubu Resort Kabupaten Kubu Raya),” J. Mhs. Tek. Sipil Univ. Tanjungpura, vol. 4, pp. 1-10.

[7] L. Mulyadi, E. H. D. Putranto, and M. N. Huda, "Evaluasi Pengaruh Kinerja Mandor terhadap Kualitas Pekerjaan Pembangunan Gedung di Kabupaten Malang," Manaj. Proy., vol. 5, pp. 14-25.

[8] H. S. Youngky, "Pengaruh Kompetensi Mandor Terhadap Kualitas Bangunan Gedung Di Kabupaten Malang," Sist. J. Ilmu-Ilmu Tek., vol. 9, pp. 22-33, 2013.

[9] U. Kalsum and M. Ibrahim, "Pengaruh Pengawasan Mandor terhadap Produktivitas Kerja Karyawan Bagian Proses Produksi pada PT. Surisenia Plasmataruna Kabupaten Rokan Hulu,” JOM FISIP, vol. 1.

[10] A. Zainullah, A. Suharyanto, and S. P. Budi, "Pengaruh Upah, Kemampuan, dan Pengalaman Kerja terhadap Kinerja Pekerja Pelaksanaan Bekisting Pada Pekerjaan Beton,” Rekayasa Sipil, vol. 6, pp. 125-133, 2012.

[11] D. G. Hendra, P. W. Arta, and N. Sugihartini, "Pengembangan Media Pembelajaran Berbasis Web Untuk Matakuliah Kurikulum dan Pengajaran di Jurusan Pendidikan Teknik Informatika Universitas Pendidikan Ganesha," J. Nas. Pendidik. Tek. Inform., vol. 5, pp. 149-157.

[12] R. Sahid, "No Title," Cara Mengatasi Soal Angket yang Tidak Valid, 2013. [Online]. Available: https://www.konsistensi.com/2014/03/mengatasi-angkettidak-valid.html. 